\title{
PENERAPAN MELIPAT, MENGGUNTING, MENEMPEL (3M) DALAM UPAYA MENINGKATKAN KETERAMPILAN MOTORIK HALUS ANAK
}

\author{
Dyah Ageng Pramesty Koenarso \\ Instansi Asal Penulis, Prodi PG-PAUD Universitas Negeri Malang \\ Email: dyahageng@ymail.com
}

Diterima: 07 Maret 2017. Disetujui: 14 Juni 2017. Dipublikasikan: 03 Agustus 2017

\begin{abstract}
The purpose of this study were 1) To determine the application in an effort to improve fine motor skills of children in B1 group at TK Negeri Pembina 2 Kecamatan Blimbing Kota Malang and 2) To describe an increase in fine motor skills of children in B1 group at TK Negeri Pembina 2 Kecamatan Blimbing Kota Malang through that implementation. The design of the study is a Classroom Action Research (CAR) with two cycles. 3M conducted in accordance with the application of design daily activities and measures adapted to the conditions and the ability of school children so that children feel comfortable when doing the application of fold, cut and paste. The results showed that there was an increase in fine motor skills of children. The classical improvement at the first cycle was in an average grade $54,51 \%$ and in the second cycle was an average grade $75,35 \%$. The analysis conclud that the implemantation.
\end{abstract}

Key Words: The implementation of fold, cut and paste, Children's Fine Motor Skills

\section{ABSTRAK}

Penelitian ini berlatar belakang pada rendahnya kemampuan motorik halus anak kelompok B1 di TK Negeri Pembina 2 Kecamatan Blimbing Kota Malang pada pembelajaran melipat, menggunting, dan menempel. Penelitian ini dilakukan karena guru mengalami kesulitan dalam memberi pemahaman pada anak. Penelitian ini bertujuan untuk mengatasi permasalahan dalam usaha mengembangkan motorik halus anak dalam berolah tangan. Kegiatan 3M yang dilakukan secara berulang-ulang, diharapkan anak dapat lebih terampil dan menyenangi kegiatan ini. Penelitian ini adalah Penelitian Tindakan Kelas (PTK) dengan dua siklus. Hasil penelitian menunjukkan bahwa terdapat peningkatan keterampilan motorik halus anak dari siklus I dengan nilai rata-rata kelas 54,51\% dan meningkat pada siklus dua dengan nilai rata-rata kelas $75,35 \%$.

Kata Kunci: Penerapan 3M (melipat, menggunting, menempel), Motorik Halus Anak mengembangkan semua potensi yang

\section{PENDAHULUAN} dimiliki anak. Dan salah satu potensi

Montessori dalam Nurani Yuliani, Sujiono dkk (2007: 2.6) mengatakan bahwa masa ini ditandai dengan masa peka terhadap segala stimulus yang diterimanya melalui panca inderanya. Masa perkembangan Anak Usia Dini (AUD) merupakan masa yang paling tepat untuk

yang perlu dikembangkan pada masa ini adalah perkembangan motorik anak.Perkembangan motorik diartikan sebagai perkembangan dari unsur kematangan dan pengendalian gerak tubuh. 
Ada tiga unsur yang menentukan perkembangan motorik yaitu otak, saraf dan otot. Ketika motorik bekerja, ketiga unsur tersebut melaksanakan tugas masingmasing peranannya secara interaksi positif, artinya unsur-unsur yang satu saling berkaitan, saling menunjang, saling melengkapi dengan unsur yang lainnya untuk mencapai kondisi motoris yang lebih sempurna keadaannya, jadi ketiga unsur tersebut saling bekerjasama

sehingga terbentuk suatu gerakan yang bertujuan. (Depdiknas dalam Sriyani, 2011). Menurut Hildayani, dkk (2009) Perkembangan motorik anak meliputi motorik kasar dan halus. Motorik kasar merupakan koordinasi otot-otot besar dengan bagian-bagian tubuh pada anak seperti memanjat, berlari, melompat, berdiri dengan satu kaki selama lebih dari sepuluh detik, dan lain sebagainya. Sedangkan motorik halus adalah gerakan anak yang menggunakan otot halus dan sebagian anggota tertentu yaitu koordinasi bagian kecil dari tubuh, terutama tangan dengan panca indera. Anak sudah dapat menggunakan kemampuannya untuk mengurus diri sendiri dengan sedikit pengawasan orang dewasa. Kelenturan tangannya pun makin baik, anak mulai dapat menggunakan tangannya untuk berkreasi.Salah satu kemampuan pada setiap anak yang dapat dikembangkan oleh guru dalam kegiatan pembelajaran di sekolah adalah keterampilan motorik halusnya. Keterampilan motorik halus adalah aktivitas yang memerlukan pemakaian otot-otot kecil pada tangan. Hampir sepanjang hari di sekolah, anak menggunakan keterampilan motorik halusnya. Bagi anak usia pra sekolah, kemampuan motorik halus merupakan hal yang sangat penting dan sangat diperlukan dalam berbagai macam aktivitas kehidupannya sehari-hari.Sulitnya anak mengembangkan kemampuan dalam melipat, menggunting dan menempel yang merupakan salah satu dari perkembangan motorik halus, karena kurang bervariasinya penggunaan metode mengajar untuk meningkatkan semangat dan kemampuan anak. Sehingga menyebabkan anak menjadi malas, tidak semangat, dan akhirnya ramai sendiri ketika diberi tugas melipat, menggunting dan menempel. Pada dasarnya anak mempunyai potensi berkembang, namun potensi anak berkembang sesuai dengan irama dan tempo perkembangan masing-masing individu. 3M merupakan salah satu kegiatan yang dapat dijadikan pembelajaran inovatif untuk mengembangkan keterampilan motorik halus anak dalam berolah tangan dengan memadukan kegiatan melipat, menggunting dan menempel. Setiap aktivitas dalam kegiatan pembelajaran, guru berperan sebagai fasilitator yang harus mengarahkan anak dalam kegiatan bermainnya, yaitu dengan memberikan bimbingan, motivasi, serta kesempatan yang berharga untuk mengekspresikan gagasan menjadi karya nyata.Tujuan dari kegiatan 3M diantaranya adalah dapat meningkatkan kemampuan psikomotorik anak-anak, memberikan tambahan referensi metode pengajaran di Taman Kanak-Kanak, dan didapatkannya peningkatan hasil kualitas anak dengan adanya penyegaran yang didapatkan dari kegiatan 3M.

\section{METODEPENELITIAN}

Penelitian ini menggunakan jenis Penelitian Tindakan Kelas (PTK) kolaboratif. Dalam pelaksanaannya peneliti dibantu oleh teman sejawat yaitu Ibu Tamsirah, S.Pd, guru tersebut bertugas mengobservasi pada saat peneliti melaksanakan tindakan (mengajar). Selain itu juga sebagai teman diskusi dalam menganalisis data dan melakukan refleksi.Penelitian tindakan kelas ini dilaksanakan di TK Negeri Pembina $2 \mathrm{Jl}$. L.A Sucipto Gang Makam Kecamatan BlimbingKota Malang dan subyek penelitian ini adalah anak kelompok B1 tahun ajaran 2011/ 2012 dengan jumlah 
sebanyak 24 anak, yang terdiri dari 10anak laki-laki dan 14 anak perempuan.Data yang digunakan dalam penelitian ini meliputi aktivitas guru dan anak pada penerapan $3 \mathrm{M}$ dan hasil karya anak untuk mengetahui kemampuan motorik halus anak. Dan sumber data dalam penelitian ini adalah guru dan anak kelompok B1 TK Negeri Pembina 2 Kecamatan Blimbing Kota Malang tahun ajaran 2011/ 2012. Teknik pengumpulan datanya menggunakan 1) Observasi atau pengamatan dilakukan untuk mengamati proses pembelajaran berlangsung yaitu untuk mengumpulkan data tentang aktivitas belajar anak (tingkat ketertarikan, kemauan, keaktifan anak) dalam 3M, penerapan $3 \mathrm{M}$ dalam meningkatkan keterampilan motorik halus dan penilaian hasil karya anak. 2) Lembar Pengamatan Proses Belajar Mengajardigunakan untuk mengumpulkan data tentang keaktifan guru dalam proses belajar mengajar dari kegiatan awal sampai dengan kegiatan akhir. Dan 3) Dokumentasi dilakukan melalui foto untuk mengumpulkan data tentang berbagai peristiwa dalam proses dan hasil karya anak.Data yang telah terkumpul dianalisis secara deskriptif kuantitatif dan kualitatif, yaitu tentang aktivitas belajar anak (tingkat ketertarikan, kemauan, keaktifan anak) dalam 3M, kemampuan dalam melipat kertas, menggunting kertas, dan menempel hasil guntingan dan lipatandengan memberi tanda contreng $(\sqrt{ })$.Dalam upaya meningkatkan kemampuan motorik halus anak melalui 3M, guru memiliki kebijakan untuk menentukan nilai minimal dalam belajar. Apabila dalam nilai akhir ada anak yang memiliki nilai di bawah nilai minimal, maka anak tersebut dinyatakan masih belum mengalami peningkatan pada kemampuan motorik halusnya. Namun jika anak memiliki nilai diatas nilai minimal, maka anak tersebut dinyatakan mengalami peningkatan pada kemam-puan motorik halusnya. Dikatakan mencapai keberhasilan jika tingkat penguasaannya lebih dari $75 \%$ dan belum mencapai keberhasilan jika penguasaan-nya kurang dari $75 \%$.

\section{HASIL DAN PEMBAHASAN}

Berikut ini paparan data dari kegiatan penelitian tindakan kelas pada anak kelompok B1 dalam meningkatkan kemampuan motorik halus melalui kegiatan 3M (Melipat, Menggunting, Menempel).

\section{Data Pra Tindakan}

Berdasarkan observasi sebelum tindakan yang dilakukan oleh peneliti di TK Negeri Pembina 2 Kecamatan Blimbing Kota Malang, kegiatan melipat, menggunting dan menempel pada anak kelompok B1 belum mencapai hasil maksimal. Dari 24 anak, ada 14 anak $(58,33 \%)$ yang mengatakan tidak bisa dan enggan mengerjakan tugasnya, 8 anak $(33,33 \%)$ yang tetap mengikuti arahan guru dengan terpaksa dan 2 anak (8,33\%) mengerjakan dengan senang hati. Hal tersebut disebabkan karena guru mengalami kesulitan dalam memberi pemahaman pada anak karena anak cenderung ingin ditunggui satu per satu dan selalu mengatakan "tidak bisa" apabila mengerjakan tugas dari guru.

Dari hasil observasi diperlukan tindakan agar kemampuan motorik halus anak dapat meningkat, berdasarkan hasil penelitian pada siklus I dan siklus II terdapat beberapa temuan pada saat kegiatan 3M (Melipat, Menggunting dan Menempel) dalam upaya meningkatkan motorik halus anak kelompok B1 TK Negeri Pembina 2 Kecamatan Blimbing Kota Malang, antara lain:

\section{Temuan Siklus I}

Pada siklus I dikemukakan beberapa temuan penelitian saat kegiatan belajar mengajar berlangsung yaitu penerapan 3M (Melipat, Menggunting, Menempel) mampu meningkatkan keterampilan motorik halus anak dan juga menumbuhkan semangat belajar anak.

Penerapan 3M dapat meningkatkan keterampilan motorik halus anak. Hal ini dibuktikan dengan meningkatnya 
keterampilan motorik halus anak dalam kegiatan $3 \mathrm{M}$ yang terdiri dari melipat, menggunting dan menempel. Disamping meningkatkan keterampilan motorik halus anak, kegiatan 3M juga dapat menumbuhkan semangat belajar anak. Semangat belajar anak ditunjukkan pada awal kegiatan yaitu ketika guru memperlihatkan alat dan bahan yang akan digunakan, anak-anak langsung mengajukan pertanyaan dan juga nampak ketika kegiatan 3M sudah dimulai. Selain rasa ingin tahu yang tinggi dan keaktifan anak dalam kegiatan pembelajaran, anak juga menunjukkan rasa senang mereka ketika kegiatan belajar mengajar berlangsung.

Kekurangan yang terjadi pada siklus I adalah guru belum mampu menguasai kelas, anak masih cenderung ramai dalam belajar, masih banyak anak yang kurang percaya diri/ ragu-ragu dalam kegiatan melipat sesuai dengan tahapan yang telah dicontohkan oleh guru dan anak juga masih mengalami kesulitan dalam menggunting kertas mengikuti garis.

\section{Temuan Siklus II}

Pada siklus II kegiatan belajar mengajar berjalan lebih baik dibandingkan siklus I. Pada saat $3 \mathrm{M}$ kerapian dan ketepatan anak dalam melipat, menggunting dan menempel sudah lebih baik hal ini dapat dilihat dari hasil karyanya. Keterampilan dan kemauan anak dalam 3M sudah lebih baik, hal ini terlihat pada saat proses kegiatan berlangsung anak sudah dapat mengikuti petunjuk guru dengan baik dan ada anak yang lebih terampil membantu temannya untuk mengajari cara melipat, menggunting dan menempel sesuai dengan petunjuk guru. Rasa percaya diri anak pun lebih meningkat dalam kegiatan 3M, anak sudah tidak ragu-ragu lagi dalam melaksanakan kegiatan.

Pada siklus II nilai ketuntasan klasikal mencapai $75,35 \%$, sehingga hasil pembelajaran sudah memenuhi standar yang ditetapkan. Adanya anak yang belum tuntas pada siklus II dalam kegiatan 3M dikarenakan anak tersebut mengalami masalah di rumah sehingga kegiatan belajarnya terganggu.

Temuan Lengkap

Berdasarkan hasil analisis data pada penelitian siklus I dan siklus II, dapat dihitung peningkatan kemampuan motorik halus anak dalam kegiatan 3M.

Tabel 1. Peningkatan siklus I ke siklus II

\begin{tabular}{lll}
\hline No & Penelitian & $\begin{array}{l}\text { Rata-rata } \\
\text { Hasil } \\
\text { (dalam \%) }\end{array}$ \\
\hline 1 & Siklus I & 54,51 \\
\hline 2 & Siklus II & 75,35 \\
\hline & Peningkatan & $\mathbf{2 0 , 8 4}$ \\
\hline
\end{tabular}

Dari tabel 1 dapat diketahui bahwa penerapan $3 \mathrm{M}$ dalam meningkatkan keterampilan motorik halus anak dapat meningkat. Hal ini terlihat pada penelitian siklus I mencapai skor rata-rata sebesar $54,51 \%$ dan pada siklus II mencapai skor rata-rata sebesar $75,35 \%$. Ada 2 anak yang tidak tuntas dalam kegiatan $3 \mathrm{M}$ ini mempengaruhi peningkatan yang terjadi secara klasikal pada siklus I ke siklus II karena anak tersebut mengalami masalah di rumah sehingga tidak ingin mengerjakan kegiatan $3 \mathrm{M}$ malah mengganggu temannya yang lain. Maka dari itu peningkatannya hanya mencapai $20,84 \%$.

\section{PEMBAHASAN}

Penerapan 3M Dalam Upaya Meningkatkan Keterampilan Motorik Halus Anak Kelompok B1 TK Negeri Pembina 2 Kecamatan Blimbing Kota Malang.

Pelaksanaan 3M (Melipat, Menggunting, Menempel) dilaksanakan melalui 3 tahap yaitu tahap pra tindakan, siklus I dan siklus II. Terlaksananya penerapan $3 \mathrm{M}$ dalam upaya meningkatkan kemampuan motorik halus ini karena didukung oleh rancangan pembelajaran yang memuat beberapa indikator tentang motorik halus.

Pada penelitian ini, guru mengajak anak untuk melakukan kegiatan 3M dengan tema pekerjaan. Pada siklus I anak diajak untuk melakukan kegiatan 3M 
dengan tema Pak Pos dan Pak Polisi. Anak terlihat senang dan bersemangat untuk melaksanakan kegiatan yang telah dirancang oleh guru. Kekurangan yang terjadi pada siklus I yaitu guru belum mampu menguasai kelas, anak masih cenderung ramai dalam belajar, masih banyak anak yang kurang percaya diri/ ragu-ragu dalam kegiatan melipat sesuai dengan tahapan yang telah dicontohkan oleh guru dan anak juga masih mengalami kesulitan dalam menggunting kertas mengikuti garis.

Pada siklus II anak diajak untuk melakukan kegiatan $3 \mathrm{M}$ dengan tema Peternak dan Tukang Kayu, peneliti mengadakan tanya jawab untuk membangkit-kan rasa percaya diri, memberikan penghargaan bagi anak yang mau menyelesai-kan kegiatannya sampai selesai dan menyiapkan bahan, media, serta teknik yang kreatif dalam kegiatan $3 \mathrm{M}$.

Keterampilan dan kemauan anak dalam 3M sudah lebih baik, hal ini terlihat pada saat proses kegiatan berlangsung anak sudah dapat mengikuti petunjuk guru dengan baik dan ada anak yang lebih terampil membantu temannya untuk mengajari cara melipat, menggunting dan menempel sesuai dengan petunjuk guru. Rasa percaya diri anak pun lebih meningkat dalam kegiatan 3M, anak sudah tidak ragu-ragu lagi dalam melaksanakan kegiatan. Adanya anak yang belum tuntas pada siklus II dalam kegiatan 3M dikarenakan anak tersebut mengalami masalah di rumah sehingga kegiatan belajarnya terganggu.

Adapun

langkah-langkah pelaksanaannya sebagai berikut: 1) Anak diajak untuk menyebutkan warna kertas lipat yang telah disediakan. 2) Anak diperlihat-kan hasil yang sudah jadi. 3) Guru membagikan kertas lipat yang sebaiknya berwarna, sementara guru juga memegang beberapa lembar kertas. 4) Guru mengajak anak untuk membuat bentuk kertas sesuai dengan lipatan yang akan dibuatnya. Misal: segitiga sama sisi, segitiga sama kaki, persegi, dan persegi panjang. 5) Mulai melakukan dengan pendekatan showing (tunjukkan), doing (lakukan) dan telling (jelaskan). 6) Beri pujian dan motivasi selama kegiatan $3 \mathrm{M}$ berlangsung. 7) Begitu pula hal yang dilakukan dalam menggunting dan menempel, guru perlu memperagakan terlebih dahulu bagaimana cara mengerjakannya. 8) Anak diminta untuk menempel hasil guntingannya pada kertas yang agak tebal menggunakan lem dengan usaha dan caranya sendiri tanpa bantuan orang lain. Anak diberi kebebasan untuk menuangkan ide menyusun dan meng-atur hasil guntingannya tersebut, berikan stimulasi serta pujian dari hasil karya-nya. 9) Guru perlu berkeliling, mengamati, berkomunikasi dan membantu anak yang mengalami kesulitan. 10) Bila terdapat anak yang mengalami kesulitan berikan pengarahan mengenai langkah-langkah pengerjaannya, hindari memberi bantuan langsung, upayakan anak mengerjakan sendiri.

Hal ini sesuai dengan yang dikemukakan Gordon \& Browne dalam Moeslichatoen(2004: 16) "Dalam mengembangkan keterampilan motorik diper-lukan keterampilan mengingat dan mengalami. Anak mengingat gerakan motorik yang telah dilakukan agar dapat melakukan perbaikan dan penghalusan gerak". Pengalaman yang diperoleh anak dan keterampilan mengingat yang dimilikinya merupakan hal penting bagi anak dalam memperoleh keterampilan motorik tertentu, dengan kata lain keterampilan motorik memerlukan latihanlatihan.

\section{Peningkatan Keterampilan Motorik Halus Melalui Penerapan 3M Pada Anak Kelompok B1 TK Negeri Pembina 2 Kecamatan Blimbing Kota Malang.}

Penerapan 3M dapat meningkatkan keterampilan motorik halus anak. Hal ini dibuktikan dengan meningkatnya keterampilan motorik halus anak dalam kegiatan $3 \mathrm{M}$ yang terdiri dari melipat, 
menggunting dan menempel. Sebagaimana dijelaskan oleh Dra. Sandra Talogo, Psi. MSc. dalam Tabloid Nakita mengatakan bahwa menggerak-gerakkan gunting, mengikuti alur guntingan kertas merupakan kegiatan yang efektif untuk mengasah kemampuan motorik halus anakbegitu juga dengan kegiatan menempel (Talogo, 2004).

Terbukti pula berdasarkan data rekapitulasi kegiatan belajar anak dapat diketahui bahwa terdapat peningkatan hasil belajar anak dalam keterampilan motorik halus anak melalui 3M (melipat, menggunting, menempel).

Pada siklus I pertemuan 1 hasil observasi penerapan $3 \mathrm{M}$ dalam upaya meningkatkan keterampilan motorik halus anak mencapai $48,96 \%$ dan pertemuan 2 sebesar $60,07 \%$. Diperoleh hasil rata-rata sebesar $54,51 \%$ sehingga mengalami peningkatan pada siklus I sebesar $11,11 \%$. Karena kemampuan motorik halus anak dengan penerapan $3 \mathrm{M}$ belum mencapai standar minimal $75 \%$, maka peneliti melanjutkan penelitian lagi pada siklus II.

Pada penelitian siklus II pertemuan 1 mencapai 70,83\% dan pertemuan 2 sebesar $79,86 \%$. Diperoleh hasil rata-rata sebesar $75,35 \%$ sehingga mengalami peningkatan pada siklus II sebesar 9,03\%. Maka dapat dilihat bahwa ada peningkatan kemampuan motorik halus anak dengan 3M dari siklus I ke siklus II sebesar $20,84 \%$. Hal ini menunjukkan bahwa keterampilan motorik halus anak dari siklus I ke siklus II mengalami peningkatan. Adanya anak yang belum tuntas pada siklus II dikarenakan anak tersebut mengalami masalah di rumah sehingga tidak ingin mengerjakan kegiatan 3M malah mengganggu temannya yang lain. Maka dari itu peningkatannya hanya mencapai $20,84 \%$ dan mempengaruhi peningkatan yang terjadi secara klasikal pada siklus I ke siklus II.

Tetapi karena keterampilan motorik halus anak secara klasikal dengan penerapan $3 \mathrm{M}$ sudah mencapai $75,35 \%$, maka peneliti mengakhiri penelitian ini pada siklus II. Adanya peningkatan ini mendukung tujuan penelitian yang diajukan bahwa penerapan 3M dapat meningkatkan keterampilan motorik halus anak di kelompok B1 TK Negeri Pembina 2 Kecamatan Blimbing Kota Malang.

\section{PENUTUP \\ Kesimpulan}

Berdasarkan hasil dan pembahasan penelitian yang telah dipaparkan, maka peneliti dapat menarik kesimpulan sebagai berikut: 1) Penerapan 3M dapat meningkatkan keterampilan motorik halus anak kelompok B1 di TK Negeri Pembina 2 Kecamatan Blimbing Kota Malang dan dilaksanakan sesuai dengan RKH yang disesuaikan dengan kondisi sekolah serta kemampuan anak agar anak merasa nyaman ketika melakukan kegiatan 3M. Adapun langkah-langkah pelaksanaannya sebagai berikut: a) Anak diajak untuk menyebutkan warna kertas lipat yang telah disediakan. b) Anak diperlihatkan hasil yang sudah jadi. c) Guru membagikan kertas lipat yang sebaiknya berwarna, sementara guru juga memegang beberapa lembar kertas. d) Guru mengajak anak untuk membuat bentuk kertas sesuai dengan lipatan yang akan dibuatnya. Misal: segitiga sama sisi, segitiga sama kaki, persegi, dan persegi panjang. e) Mulai melakukan dengan pendekatan showing (tunjukkan), doing (lakukan) dan telling (jelaskan). f) Beri pujian dan motivasi selama kegiatan 3M berlangsung. g) Begitu pula hal yang dilakukan dalam menggunting dan menempel, guru perlu memperagakan terlebih dahulu bagaimana cara mengerjakannya. h) Anak diminta untuk menempel hasil guntingannya pada kertas yang agak tebal menggunakan lem dengan usaha dan caranya sendiri tanpa bantuan orang lain. Anak diberi kebebasan untuk menuang-kan ide menyusun dan mengatur hasil guntingannya tersebut, berikan stimulasi serta pujian dari hasil karyanya. i) Guru perlu berkeliling, mengamati, berkomunikasi dan membantu anak yang mengalami kesulitan. j) Bila 
terdapat anak yang mengalami kesulitan berikan pengarahan mengenai langkahlangkah pengerjaan-nya, hindari memberi bantuan langsung, upayakan anak mengerjakan sendiri. 2) Keterampilan motorik halus dengan menerapkan 3M dapat dikatakan meningkat dengan baik dan signifikan. Ketuntasan klasikal pada siklus I dengan nilai rata-rata kelas $54,51 \%$ dan ketuntasan klasikal siklus II dengan nilai rata-rata kelas $75,35 \%$. Maka dapat dilihat ada peningkatan kemampuan motorik halus anak dengan $3 \mathrm{M}$ dari siklus I ke siklus II sebesar $20,84 \%$ hal ini menunjukkan bahwa pada pembelajaran tersebut menarik perhatian anak, sehingga anak lebih termotivasi. Adanya anak yang belum tuntas pada siklus II dikarenakan anak tersebut mengalami masalah di rumah sehingga tidak ingin mengerjakan kegiatan 3M malah mengganggu temannya yang lain. Maka dari itu peningkatannya hanya mencapai 20,84\% dan mempengaruhi peningkatan yang terjadi secara klasikal pada siklus I ke siklus II.

\section{Saran}

Setelah mengetahui hasil dan kesimpulan selama penelitian berlangsung pada anak kelompok B1 di TK Negeri Pembina 2 Kecamatan Blimbing Kota Malang, ada beberapa saran mengenai perkembangan lebih lanjut merujuk pada hasil penelitian tindakan kelas ini dan saran yang membangun agar dapat mem-perbaiki atau meningkatkan kualitas proses belajar mengajar selanjutnya. 1) Saran bagi lembaga (sekolah). Peralihan bentuk pendidikan informal/keluarga ke formal/sekolah memerlukan kerjasama antara orang tua dan sekolah (pendidik). Sikap anak terhadap sekolah terutama akan dipengaruhi oleh sikap orang tua mereka. Sehingga diperlukan kepercayaan orang tua terhadap sekolah (pendidik) yang menggantikan tugasnya selama di sekolah. Orang tua harus memperhatikan sekolah anaknya dengan memperhatikan pengalaman-pengalamannya dan menghargai usaha-usahanya, menunjukkan kerjasamanya dalam cara anak belajar di rumah dan atau membuat pekerjaan rumahnya.Hasil penelitian ini dapat digunakan sebagai tambahan referensi metode pengajaran dan bahan pertimbangan dalam memahami karakteristik serta penanganan anak, khususnya untuk mengembangkan motorik halus anak melalui kegiatan bermain. 2) Bagi Pendidik (Guru). Dalam kegiatan pembelajaran dilaksanakan sesuai dengan RKH yang disesuaikan dengan kondisi sekolah serta kemampuan anak agar anak merasa nyaman ketika melakukan kegiatan. Sangat diperlukan untuk mempersiapkan alat dan bahan yang digunakan sebaiknya yang aman bagi anak, seperti penggunaan gunting berdasarkan bahannya. Sehingga apa yang akan dikerjakan tampak lebih terencana dengan baik dan dapat mempengaruhi pencapaian yang didapat oleh anak selain itu dapat dilakukan dengan penerapan kegiatan-kegiatan yang aktif, kreatif dan menyenangkan sehingga anak tidak cepat merasa bosan. Serta dilakukan secara bertahap dan berulang-ulang sesuai dengan kemampuan anak. 3) Bagi Peneliti Pendidikan. Penelitian ini dapat digunakan sebagai rujukan pengetahuan dan pengalaman dalam kegiatan belajar mengajar sebagai contoh peningkatan kemampuan motorik halus pada anak usia dini melalui kegiatan 3M (melipat, menggunting, menempel) ini, namun kajiannya masih sangat terbatas yaitu pada bidang kemampuan motorik halus melalui kegiatan 3M, sehingga masih diperlu-kan pengetahuan peningkatan kemampuan motorik halus anak melalui kegiatan lain selain $3 \mathrm{M}$. 


\section{DAFTAR PUSTAKA}

Hildayani dkk, Rini. (2009). Psikologi Perkembangan Anak . Jakarta: Universitas Terbuka

Moeslichatoen. (2004). Metode Pengajaran di Taman Kanakkanak. Jakarta: PT Rineka Cipta.

Nurani Yuliani, Sujiono dkk. (2007). Metode Pengembangan Kognitif. Jakarta: Universitas Terbuka.

Sriyani. (2011). Penerapan Metode Demonstrasi Untuk Meningkatkan Kemampuan Motorik Halus Khususnya Dalam Melipat Pada Anak Kelompok A Di TK Al Hidayah Bendo Kota Blitar. (Tidak diterbitkan), Skripsi: Universitas Negeri Malang.

Talogo, Sandra. (2004). Kreatif Lewat Menggunting dan Menempel. (online), dalam Tabloid Nakita
Nomor 260 Tahun V

(http://www.tabloid-

nakita.com/artikel.php3 ?edisi=052

60\&rubrik=prasekolah) diakses tanggal 10 November 2011. 